\title{
Preparation of Chloro Penta Amine Cobalt(III) Chloride and Study of Its Influence on the Structural and Some Optical Properties of Polyvinyl Acetate
}

\author{
Nada K. Abbas, ${ }^{1}$ Majeed Ali Habeeb, ${ }^{2}$ and Alaa J. Kadham Algidsawi ${ }^{3}$ \\ ${ }^{1}$ Department of Physics, College of Science for Women, Baghdad University, Baghdad, Iraq \\ ${ }^{2}$ Department of Physics, College of Education of Pure Sciences, University of Babylon, Babylon, Iraq \\ ${ }^{3}$ Department of Soil and Water, College of Agriculture, AL-Qasim Green University, Babylon, Iraq \\ Correspondence should be addressed to Alaa J. Kadham Algidsawi; alaa.algidsawi@yahoo.com
}

Received 21 September 2014; Revised 24 December 2014; Accepted 27 January 2015

Academic Editor: Önder Pekcan

Copyright ( 2015 Nada K. Abbas et al. This is an open access article distributed under the Creative Commons Attribution License, which permits unrestricted use, distribution, and reproduction in any medium, provided the original work is properly cited.

\begin{abstract}
Chloro penta amine cobalt(III) cloride $\left[\mathrm{Co}\left(\mathrm{NH}_{3}\right)_{5} \mathrm{Cl}_{\mathrm{Cl}} \mathrm{Cl}_{2}\right.$ was prepared and then characterized by Fourier transform infrared spectroscopy and X-ray diffraction. The obtained results indicated the formation of orthorhombic $\left[\mathrm{Co}\left(\mathrm{NH}_{3}\right)_{5} \mathrm{Cl}\right] \mathrm{Cl}_{2}$ nanoparticles of $\approx 28.75 \mathrm{~nm}$ size. Polymeric films based on polyvinyl acetate (PVAc) doped with chloro penta amine cobalt(III) cloride $\left[\mathrm{Co}\left(\mathrm{NH}_{3}\right)_{5} \mathrm{Cl}\right] \mathrm{Cl}_{2}$ in different weight percent ratios were prepared using the solvent cast technique. The complexation of the additive with the polymer was confirmed by FTIR and SEM studies. The XRD pattern revealed that the amorphousicity of PVAc polymer matrix increased with raising the $\left[\mathrm{Co}\left(\mathrm{NH}_{3}\right)_{5} \mathrm{Cl}\right] \mathrm{Cl}_{2}$ content. Parameters such as extinction coefficient, refractive index, real and imaginary parts, and optical conductivity were studied by using the absorbance and measurements from computerized UV-visible spectrophotometer in the spectral range 190-800 $\mathrm{nm}$. This study showed that the optical properties of PVAc were affected by the doping of $\left[\mathrm{Co}\left(\mathrm{NH}_{3}\right)_{5} \mathrm{Cl}\right] \mathrm{Cl}_{2}$ where the absorption increased by leveling up $\left[\mathrm{Co}\left(\mathrm{NH}_{3}\right)_{5} \mathrm{Cl}\right] \mathrm{Cl}_{2}$ concentration. The nature of electronic transition from valence band to conduction band was determined and the energy band gaps of the composite films samples were estimated by UV-visible spectrum. It was observed that the optical conductivity increased with photon energy and with the increase of $\left[\mathrm{Co}\left(\mathrm{NH}_{3}\right)_{5} \mathrm{Cl}\right] \mathrm{Cl}_{2}$ concentration.
\end{abstract}

\section{Introduction}

Polymers can exhibit various mechanical, electrical, and optical properties depending on the synthesis conditions and chemical properties of the backbone [1]. If a polymer is exposed to ultraviolet light, its chemical properties, such as solubility, of the polymer in the exposed area are changed. Photolithography, which is a well-known process in electronics, uses this principle [2].

Polymers are used in an amazing number of applications. More recently, significant developments have occurred in the area of flexible electronic devices based on the useful piezoelectric, semiconducting, optical, and electrooptical properties seen in some polymers [3].

Polymeric materials have special interest because, in combination with suitable metal salts, they give complexes which are useful for the development of advanced high energy electrochemical devices, for example, batteries, fuel cells, electrochemical display devices, and photo electrochemical cells with ease of fabrication into desirable sizes [4]. Also polymers have unique properties such as light weight, high flexibility, and ability to be fabricated at low temperature and low cost [5]. Optical communications, including polymer optical fibers, optical waveguides, and optical connectors due to their ease of process, relatively low cost, and mass production, are compared to silica-based optical materials. They also have potential advantages for applications in optical storage systems, such as high thermal stability, low absorption loss, and the ability of refractive index changing upon exposure to light [6]. The electrical and optical properties of polymers have attracted a great attention in view of their applications 
in optical devices with remarkable reflection, antireflection, interference, and polarization properties [7].

Commercial vinyl polymers such PVAc $\left(\mathrm{C}_{4} \mathrm{H}_{6} \mathrm{O}_{2}\right)_{n}$ are intensively studied because of their broad applications in industry. Polyvinyl acetate is thermoplastic polymer. PVAcbased composites materials were significantly manufactured by resin emulsifier, adhesive, paper, paint, and textile industries owing to high-bond reinforced, film-like, odorless, and nonflammable characteristic and substrate for PVA production [8]. The incorporation of various metallic additives into polymer matrices can produce polymer-matrix composites and improves its properties for specific applications [9].

Coordination compounds or metal complexes are metal ions surrounded by ligands. Ligands are either anions or molecules that can donate electrons into the d-orbitals of the metal ion and form a bond. Examples of common ligands are chloride ion, cyanide ion, ammonia, ethylenediamine, and ethylenediaminetetraacetateion (EDTA). The metal ions that form coordination compounds are from a group of metals known as transition metals. These metals have more than one oxidation state. This property allows the transition metals to act as Lewis acids [10]. The metal complex used in this paper is chloro pentammine cobalt(III) chloride which is a paramagnetic compound [11]. It decomposes upon heating above $150^{\circ} \mathrm{C}$. Its solubility is $0.4 \mathrm{~g}$ per $100 \mathrm{~mL}$ at $25^{\circ} \mathrm{C}$ [12].

In this paper an effort has been made to study the effect of addition of $\left[\mathrm{Co}\left(\mathrm{NH}_{3}\right)_{5} \mathrm{Cl}\right] \mathrm{Cl}_{2}$ on structural and optical properties of polyvinyl acetate by FTIR, XRD, SEM, and UVvisible spectrometer techniques. The results obtained from these measurements have been analyzed and discussed.

\section{Experimental}

2.1. Preparation of Chloro Penta Amine Cobalt(III) Chloride $\left[\mathrm{Co}\left(\mathrm{NH}_{3}\right)_{5} \mathrm{Cl}\right] \mathrm{Cl}_{2}$. Chloro penta amine cobalt(III) chloride $\left[\mathrm{Co}\left(\mathrm{NH}_{3}\right)_{5} \mathrm{Cl}\right] \mathrm{Cl}_{2}$ was prepared by the procedure reported in the literature [13].

$1.7 \mathrm{~g}$ of ammonium chloride $\mathrm{NH}_{4} \mathrm{Cl}$ was completely dissolved in $\sim 10 \mathrm{~mL}$ of concentrated ammonia $\mathrm{NH}_{3}$ in a $400 \mathrm{~mL}$ beaker. With continuous stirring, $3.3 \mathrm{~g}$ of cobalt(II) chloride $\mathrm{CoCl}_{2}$ was added to the mixture gradually. When brown color slurry was obtained, $2.7 \mathrm{~mL}$ of $30 \%$ hydrogen peroxide $\mathrm{H}_{2} \mathrm{O}_{2}$ was added slowly. After the effervescence had stopped, $\sim 10 \mathrm{~mL}$ of concentrated Hydrochloric acid $\mathrm{HCl}$ was add slowly. With continued stirring, the mixture is heated on a hot plate and maintains $85^{\circ} \mathrm{C}$ for 20 minutes, and then the mixture is cooled to room temperature in an ice bath and filter (using a Buchner funnel). The crystals of $\left[\mathrm{Co}\left(\mathrm{NH}_{3}\right)_{5} \mathrm{Cl}\right] \mathrm{Cl}_{2}$ are washed with $5-6$ times, $5 \mathrm{~mL}$ portions of ice water (distilled water cooled in ice) and then 5-6 times, $5 \mathrm{~mL}$ portions of ethanol $\mathrm{C}_{2} \mathrm{H}_{6} \mathrm{O}$. All chemicals used in preparation of chloro penta amine cobalt(III) chloride were purchased from Sigma-Aldrich

$$
\begin{aligned}
2 \mathrm{CoCl}_{2} \cdot 6 \mathrm{H}_{2} \mathrm{O}(\mathrm{s})+2 \mathrm{NH}_{4} \mathrm{Cl}(\mathrm{s})+8 \mathrm{NH}_{3}(\mathrm{aq}) \\
+\mathrm{H}_{2} \mathrm{O}_{2}(\mathrm{aq})+3 \mathrm{H}_{2} \mathrm{O}(\mathrm{l}) \\
\longrightarrow 2\left[\mathrm{Co}\left(\mathrm{NH}_{3}\right)_{5} \mathrm{Cl}\right] \mathrm{Cl}_{2}(\mathrm{~s})+\frac{1}{2} \mathrm{O}_{2}(\mathrm{~g})
\end{aligned}
$$

2.2. Sample Preparation. Poly(vinyl acetate) (PVAc) with molecular weight 100,000 was purchased from Aldrich. PVAc/ $\left[\mathrm{Co}\left(\mathrm{NH}_{3}\right)_{5} \mathrm{Cl}\right] \mathrm{Cl}_{2}$ composites films were fabricated by the solvent casting technique. At first emulsion of PVAc using distilled water was stirred for $10 \mathrm{~h}$. The necessary weight fractions of $\left[\mathrm{Co}\left(\mathrm{NH}_{3}\right)_{5} \mathrm{Cl}\right] \mathrm{Cl}_{2}$ were first dispersed in distilled water with a magnetic stirrer for $1 \mathrm{~h}$ and then added gradually into the polymeric emulsion with continuous stirring and kept under string for $2 \mathrm{~h}$. Finally, the solution was poured onto cleaned Petri dishes and allowed to evaporate slowly at room temperature for a week. After drying, the films were peeled from Petri dishes and kept in vacuum desiccators until use. The thickness of the obtained films was in the range of $\approx 120-150 \mu \mathrm{m}$.

X-ray diffraction scans were obtained using DX-2700 diffractometer using $\mathrm{Cu} \mathrm{K} \alpha$ radiation $(\lambda=1.5406 \AA)$ operating at $40 \mathrm{kV}$ and $30 \mathrm{~mA}$, taken for the $2 \theta$ range of 5$50^{\circ}$. Measurements were carried out at room temperature. The diffracted intensity as a function of the reflection angel was plotted automatically by the X-ray diffractometer. The various peaks obtained in the diffraction pattern gave the information about the size and interplanar spacing of the compound. FTIR was recorded on Fourier transform infrared spectrophotometer, Shimadzu, model IR-Prestige 21, using $\mathrm{KBr}$ pellets. FT-IR spectra of the samples were obtained in the spectral range of (4000-400) $\mathrm{cm}^{-1}$. Ultraviolet-visible (UVVIS) absorption spectra were measured in the wavelength region of 190-800 $\mathrm{nm}$ using double-beam spectrophotometer UV-1800 Shimadzu. The morphology of the films was characterized by scanning electron microscope using Bruker Nano $\mathrm{GmbH}$, Germany, operating at $5 \mathrm{kV}$ accelerating voltage.

\section{Results and Discussion}

3.1. X-Ray Diffraction (XRD). A typical XRD pattern for $\left[\mathrm{Co}\left(\mathrm{NH}_{3}\right)_{5} \mathrm{Cl}\right] \mathrm{Cl}_{2}$ is shown in Figure 1 . It can be seen that many sharp peaks were observed in the $\mathrm{X}$-ray profile. The crystalline nature of synthesized $\left[\mathrm{Co}\left(\mathrm{NH}_{3}\right)_{5} \mathrm{Cl}\right] \mathrm{Cl}_{2}$ was observed by the various sharp crystalline peaks in the XRD pattern. It shows diffraction peaks at 15.8313, 25.6011, 32.6249, and 34.8279 corresponding to the (011), (221), (122), and (040) planes $\left[\mathrm{Co}\left(\mathrm{NH}_{3}\right)_{5} \mathrm{Cl}\right] \mathrm{Cl}_{2}$ which could be indexed to orthorhombic structure which were consistent with the literature data of Materials Data, Inc. [14]. The average particle size can be calculated using the first sphere approximation of Debye-Scherrer formula [15]:

$$
D=\frac{0.9 \lambda}{B \cos (\theta)}
$$

where $D$ is the average diameter of the crystals, $\lambda$ is the wavelength of $\mathrm{X}$-ray radiation, and $B$ is the full width at half maximum intensity of the peak (FWHM). The obtained particle size of $\left[\mathrm{Co}\left(\mathrm{NH}_{3}\right)_{5} \mathrm{Cl}\right] \mathrm{Cl}_{2}$ is $28.75 \mathrm{~nm}$. The structural parameter such as diffraction angle $2 \theta$ (deg.), interplanar $d(\AA)$, relative intensity $\left(I / I_{\mathrm{o}}\right)$, and full width at half maximum FWHM (deg.) are in Table 1.

PVAc are semicrystalline polymers as indicated from their XRD patterns illustrated in Figure 2(a). The crystalline 
TAble 1: Diffraction angle $2 \theta$ (deg.), interplanar $d(\AA)$, relative intensity $\left(I / I_{\mathrm{o}}\right)$, and full width at half maximum FWHM (deg.).

\begin{tabular}{lcccc}
\hline Material & $2 \theta$ (deg.) & $d(\AA)$ & $I / I_{\mathrm{o}}$ & FWHM (deg.) \\
\hline & 15.7313 & 5.59343 & 100 & 0.2763 \\
{$\left[\mathrm{Co}\left(\mathrm{NH}_{3}\right)_{5} \mathrm{Cl}_{\mathrm{Cl}} \mathrm{Cl}_{2}\right.$} & 25.6011 & 3.47674 & 60 & 0.2046 \\
& 33.4837 & 2.6741 & 36 & 0.2359 \\
& 34.7279 & 2.5739 & 43 & 0.2143 \\
\hline
\end{tabular}

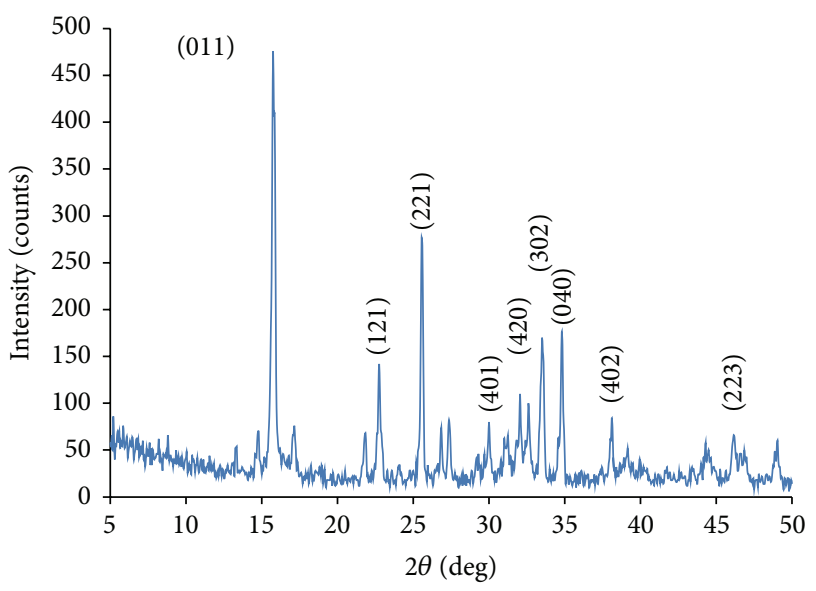

FIGURE 1: XRD pattern for $\left[\mathrm{Co}\left(\mathrm{NH}_{3}\right)_{5} \mathrm{Cl}\right] \mathrm{Cl}_{2}$ powder.

nature of PVAc is emphasized by the diffraction peaks at $2 \theta=$ $19.54^{\circ}, 40.54^{\circ}$, with a hallow shoulder at $2 \theta=23^{\circ}$ representing the amorphous phase in PVAc [16].

The function group $-\mathrm{O}-\stackrel{\mathrm{O}}{\mathrm{C}}-\mathrm{CH}_{3}$ present in the structure of PVAc has a role in increasing the carbon backbones disturbance, thus resulting in appears a crystalline phases in PVAc as shown in XRD pattern Figure 2(a) [17]. Figures 2(b), 2(c), and 2(d) explained the XRD pattern of PVAc/3, PVAc/6, and PVAc/9 wt. $\%\left[\mathrm{Co}\left(\mathrm{NH}_{3}\right)_{5} \mathrm{Cl}\right] \mathrm{Cl}_{2}$, respectively. It can be seen that the intensity of essential peak of PVAc decreased and the band width increased with increasing the concentrations of $\left[\mathrm{Co}\left(\mathrm{NH}_{3}\right)_{5} \mathrm{Cl}\right] \mathrm{Cl}_{2}$. The essential peak of PVAc represents the crystalline region in PVAc, so, the reduction of the intensity and broadening of this peak refers to decreases in crystallinity and increases in amorphousicity. This behavior demonstrates complexation between the filler and the polymers in the amorphous region [4]. The behavior of $\mathrm{PVAc} /\left[\mathrm{Co}\left(\mathrm{NH}_{3}\right)_{5} \mathrm{Cl}\right] \mathrm{Cl}_{2}$ composite agrees with $\mathrm{PVAc} / \mathrm{Pb}_{3} \mathrm{O}_{4}$ [18] and $\mathrm{PVAc} / \mathrm{TiO}_{2}$ [19]. With 9 wt. $\%$ concentration the peaks belong to $\left[\mathrm{Co}\left(\mathrm{NH}_{3}\right)_{5} \mathrm{Cl}\right] \mathrm{Cl}_{2}$ observed with lower intensity because $\left[\mathrm{Co}\left(\mathrm{NH}_{3}\right)_{5} \mathrm{Cl}\right] \mathrm{Cl}_{2}$ structure is being capped with PVAc after formation of composites, which agrees with (Roy et al. 2013) [20]. Polymers with 3-dimensional structure, such poly (vinyl acetate) (PVAc) [21] have rigid pores, that set an upper limit for additive growth inside such polymeric matrix [17].

Particle size of $\left[\mathrm{Co}\left(\mathrm{NH}_{3}\right)_{5} \mathrm{Cl}\right] \mathrm{Cl}_{2}$ particles was found according to the preferred direction plane (011) for
PVAc/ 6 wt. $\%$ and 9 wt. $\%$ of $\left[\mathrm{Co}\left(\mathrm{NH}_{3}\right)_{5} \mathrm{Cl}\right] \mathrm{Cl}_{2}$ composites film which are around $22.06 \mathrm{~nm}$ and $23.50 \mathrm{~nm}$, respectively.

3.2. Fourier Transform Infrared Spectroscopy (FTIR). FTIR spectra of $\left[\mathrm{Co}\left(\mathrm{NH}_{3}\right)_{5} \mathrm{Cl}\right] \mathrm{Cl}_{2}$ show peaks at $3278,1620,1307$, 840 , and $486 \mathrm{~cm}^{-1}$ which correspond to the $\mathrm{NH}_{3}$ stretching vibration, degeneration deformation vibration of $\mathrm{NH}_{3}$ ligand, symmetric deformation vibration of $\mathrm{NH}_{3}$, rocking vibration of $\mathrm{NH}_{3}$, and $\mathrm{Co}-\mathrm{NH}_{3}$ stretching vibrations, respectively; also $\mathrm{Co}-\mathrm{Cl}$ peak appeared around $840 \mathrm{~cm}^{-1}$. The FTIR characterization agreed with Najar and Majid (2013) [22] who investigated $\left[\mathrm{Co}\left(\mathrm{NH}_{3}\right)_{5} \mathrm{Cl}\right] \mathrm{Cl}_{2}$. The only functional group of $\left[\mathrm{Co}\left(\mathrm{NH}_{3}\right)_{5} \mathrm{Cl}\right] \mathrm{Cl}_{2}$ is $\mathrm{N}-\mathrm{H}$ which must be around $3100-3500 \mathrm{~cm}^{-1}$. Figure 3 represents the FTIR spectrum of $\left[\mathrm{Co}\left(\mathrm{NH}_{3}\right)_{5} \mathrm{Cl}\right] \mathrm{Cl}_{2}$; the $\mathrm{N}-\mathrm{H}$ is between 3161.34 and $3279.1 \mathrm{~cm}^{-1}$.

The only functional group of PVAc is $\mathrm{C}=\mathrm{O}$. Figure 4(a) represents the FTIR spectrum for PVAc, $\mathrm{C}=\mathrm{O}$ appeared around $1728.22 \mathrm{~cm}^{-1}$ [23], also C-O-C appeared around $1246 \mathrm{~cm}^{-1}$, while $\mathrm{C}-\mathrm{H}$ appeared around $2935.66 \mathrm{~cm}^{-1}$ [24]. It is worth noting that the absorption band near $3400 \mathrm{~cm}^{-1}$ is due to the $\mathrm{O}-\mathrm{H}$ groups [24]. Figures 4(b), 4(c), and 4(d) show that the PVAc absorption peaks are found to be shifted with adding $\left[\mathrm{Co}\left(\mathrm{NH}_{3}\right)_{5} \mathrm{Cl}\right] \mathrm{Cl}_{2}$. The shifting gives an insight to an interaction of the $\left[\mathrm{Co}\left(\mathrm{NH}_{3}\right)_{5} \mathrm{Cl}\right] \mathrm{Cl}_{2}$ in the polymer matrix [25]. With increasing the concentration of $\left[\mathrm{Co}\left(\mathrm{NH}_{3}\right)_{5} \mathrm{Cl}\right] \mathrm{Cl}_{2}$, the IR absorption peaks are increased due to stretching vibration shifted toward higher wave number [26], the absorption bands which belong to $\left[\mathrm{Co}\left(\mathrm{NH}_{3}\right)_{5} \mathrm{Cl}\right] \mathrm{Cl}_{2}$ become more sharper, while the intensity of PVAc absorption bands is decreased indicating an obvious presence of $\left[\mathrm{Co}\left(\mathrm{NH}_{3}\right)_{5} \mathrm{Cl}\right] \mathrm{Cl}_{2}$. The appearance of the absorption band around $1728 \mathrm{~cm}^{-1}$ for samples 3, 6, and 9 wt. $\%\left[\mathrm{Co}\left(\mathrm{NH}_{3}\right)_{5} \mathrm{Cl}\right] \mathrm{Cl}_{2}$ confirms the presence of PVAc in the samples [27]. With 3 wt.\% of $\left[\mathrm{Co}\left(\mathrm{NH}_{3}\right)_{5} \mathrm{Cl}_{2} \mathrm{Cl}_{2}\right.$, the $\mathrm{N}-$ $\mathrm{H}$ is hidden behind the $\mathrm{O}-\mathrm{H}$ rounded tip while at higher concentrations the $\mathrm{N}-\mathrm{H}$ appeared as a sharp tip.

3.3. Scanning Electron Microscope (SEM). Figures 5(a), 5(b), 5(c), and 5(d) show the SEM photographs of PVAc, PVAc $/ 3$ wt. $\%$ of $\left[\mathrm{Co}\left(\mathrm{NH}_{3}\right)_{5} \mathrm{Cl}\right] \mathrm{Cl}_{2}, \quad \mathrm{PVAc} / 6$ wt. $\%$ of $\left[\mathrm{Co}\left(\mathrm{NH}_{3}\right)_{5} \mathrm{Cl}\right] \mathrm{Cl}_{2}$, and PVAc/9 wt.\% of $\left[\mathrm{Co}\left(\mathrm{NH}_{3}\right)_{5} \mathrm{Cl}\right] \mathrm{Cl}_{2}$ composite films, respectively. In Figure 5(a), some bright undissolved PVAc grains appeared. Other spots with different degree of roughness observed on the backscattered images shown in Figures 5(b), 5(c), and 5(d) seem to be agglomerates of $\left[\mathrm{Co}\left(\mathrm{NH}_{3}\right)_{5} \mathrm{Cl}\right] \mathrm{Cl}_{2}$ particles, which increase with increasing the concentration of $\left[\mathrm{Co}\left(\mathrm{NH}_{3}\right)_{5} \mathrm{Cl}\right] \mathrm{Cl}_{2}$. The average diameters of these agglomerated particles (grains) are around $0.885,1.83$, and $2.114 \mu \mathrm{m}$ for PVAc/3, PVAc/6, and PVAc/9 wt.\% of $\left[\mathrm{Co}\left(\mathrm{NH}_{3}\right)_{5} \mathrm{Cl}\right] \mathrm{Cl}_{2}$ composite films, respectively. The change suggests that PVAc molecules may be dispersed in soft-segment phase with little influence on the microphase separation and mixing of the hard and soft segments. The degree of roughness of the film surface increases with increase of the content of $\left[\mathrm{Co}\left(\mathrm{NH}_{3}\right)_{5} \mathrm{Cl}\right] \mathrm{Cl}_{2}$. This indicates segregation of the filler in the host matrix and this may confirm the interaction and complexation between 


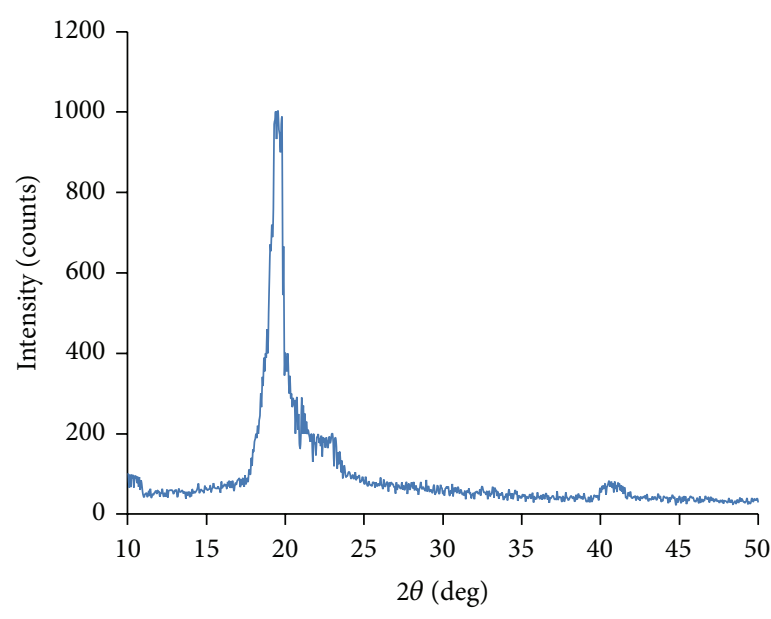

(a)

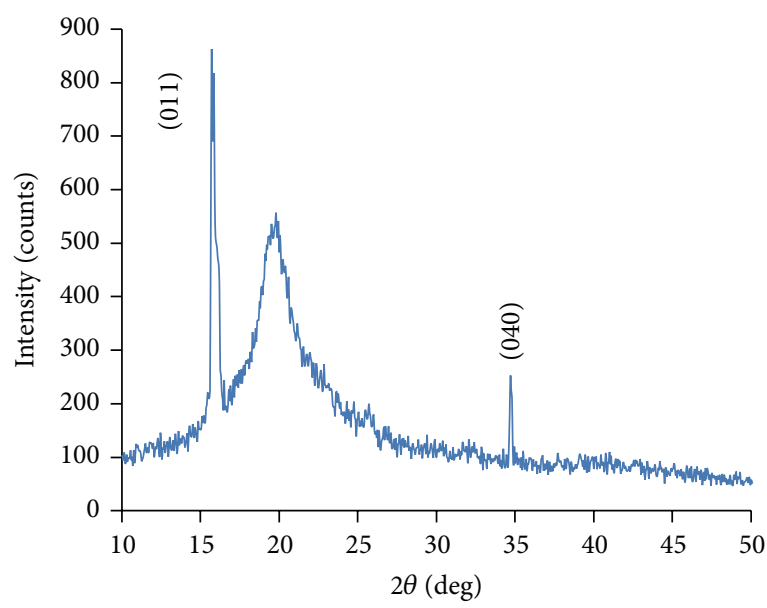

(c)

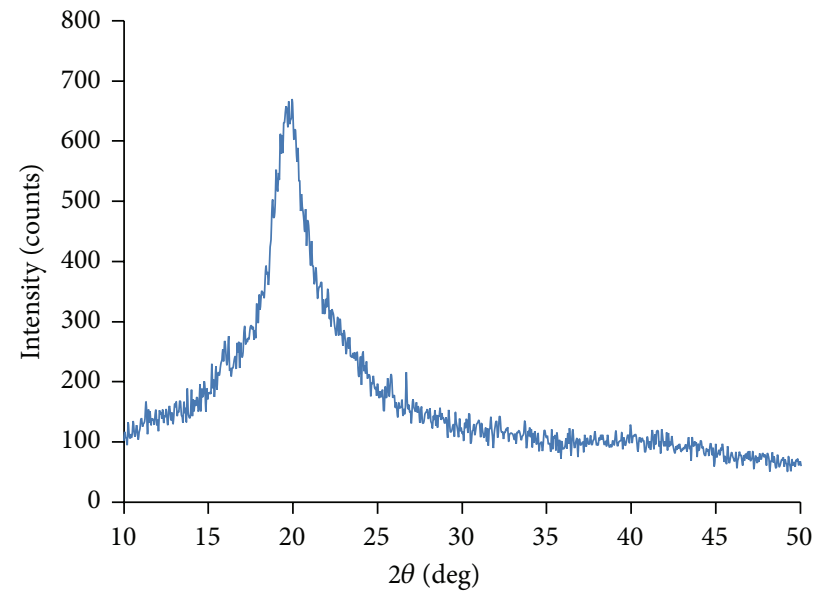

(b)

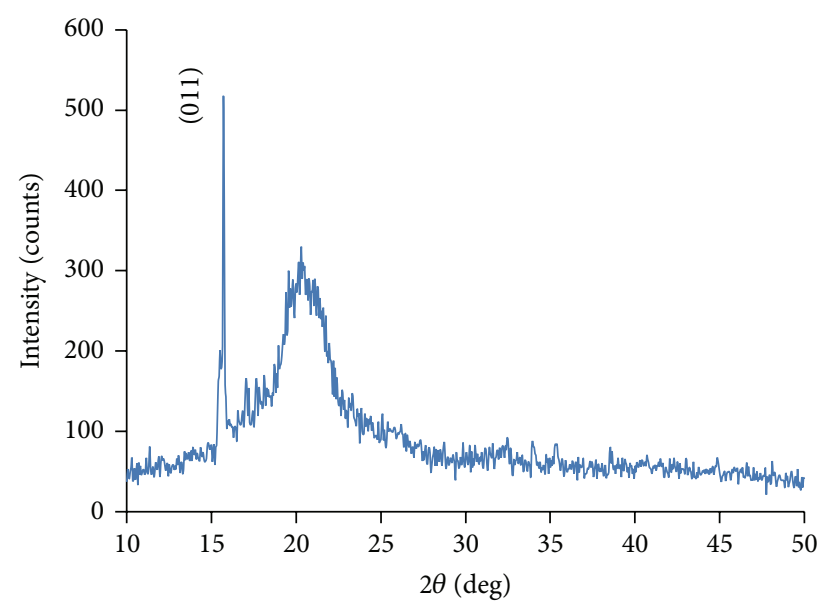

(d)

FIGURE 2: XRD pattern for PVAc/[Co( $\left.\left.\mathrm{NH}_{3}\right)_{5} \mathrm{Cl}\right] \mathrm{Cl}_{2}$ composites film with different concentrations: (a) pure PVAc, (b) 3 wt.\% (c) 6 wt.\%, and (d) 9 wt.\%.

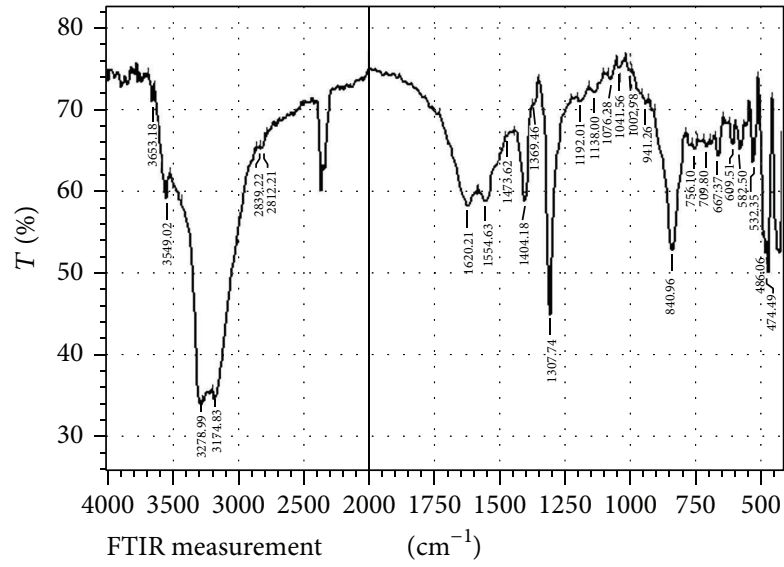

Figure 3: FTIR graph of $\left[\mathrm{Co}\left(\mathrm{NH}_{3}\right)_{5} \mathrm{Cl}\right] \mathrm{Cl}_{2}$.

the additive and the polymer [4] and also it may refer to growth of $\left[\mathrm{Co}\left(\mathrm{NH}_{3}\right)_{5} \mathrm{Cl}\right] \mathrm{Cl}_{2}$ particles in PVAc matrix [4].
3.4. UV-VIS Spectra. The absorbance spectra for PVAc/ $\left[\mathrm{Co}\left(\mathrm{NH}_{3}\right)_{5} \mathrm{Cl}\right] \mathrm{Cl}_{2}$ doped films are shown in Figure 6. As indicated in Figure $6\left[\mathrm{Co}\left(\mathrm{NH}_{3}\right)_{5} \mathrm{Cl}\right] \mathrm{Cl}_{2}$ enhances the absorbance of the PVAc host. The UV-visible absorption spectra of PVAc and PVAc/ $\left[\mathrm{Co}\left(\mathrm{NH}_{3}\right)_{5} \mathrm{Cl}\right] \mathrm{Cl}_{2}$ composites films are carried out at room temperature. The pretend spectral dependencies of optical functions unambiguously show that the principle role in the observed spectra plays electron-phonon broadening. The UV optical absorption pattern of PVAc exhibits an absorption band like shoulder at about $\lambda=$ $260 \mathrm{~nm}$. This band is attributed to the carbonyl group [28]. It is observed that the wavelength corresponding to the absorption band like shoulder increases with increasing in $\left[\mathrm{Co}\left(\mathrm{NH}_{3}\right)_{5} \mathrm{Cl}\right] \mathrm{Cl}_{2}$ content; this increase has been attributed to the minor structural inhomogeneities present in PVAc [18] which are due to growth of $\left[\mathrm{Co}\left(\mathrm{NH}_{3}\right)_{5} \mathrm{Cl} \mathrm{Cl}_{2}\right.$ inside the polymeric matrix. As the composite films show a red shift behavior, these shifts indicate the complexation between the $\left[\mathrm{Co}\left(\mathrm{NH}_{3}\right)_{5} \mathrm{Cl}\right] \mathrm{Cl}_{2}$ and the PVAc and may also be due to change in crystallinity with presence of additive [29]. 


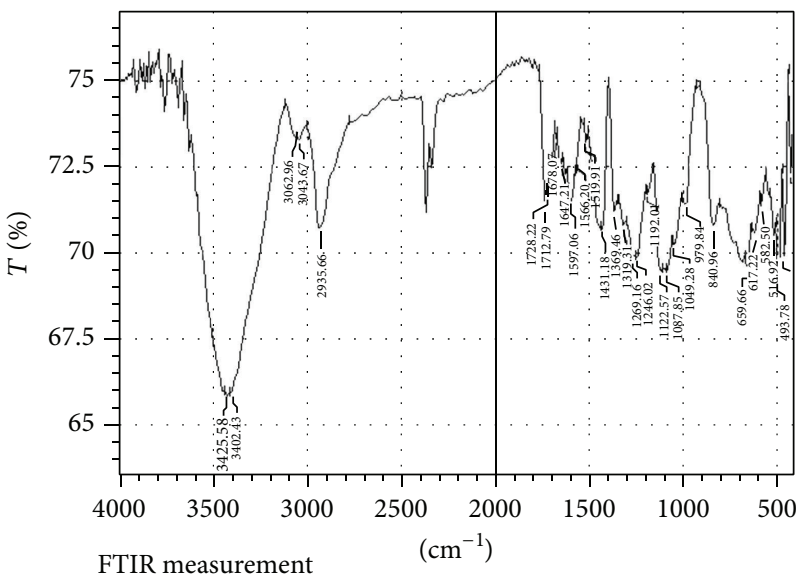

(a)

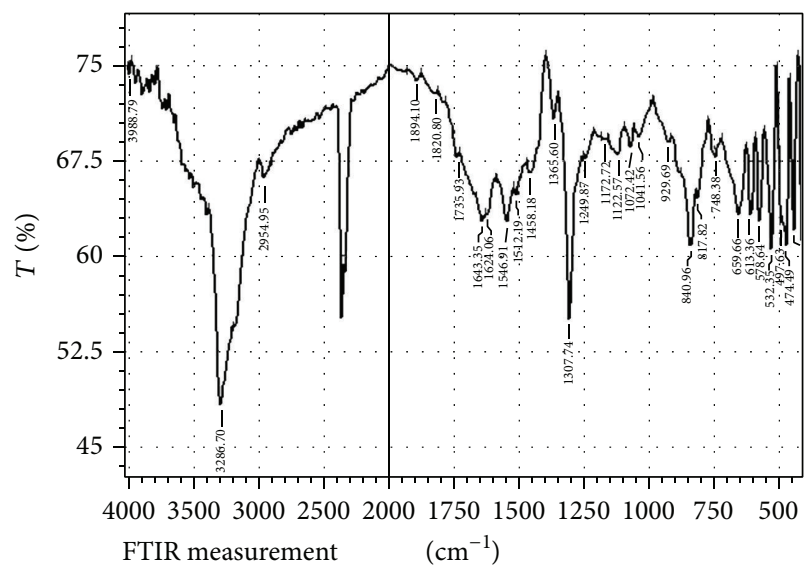

(c)

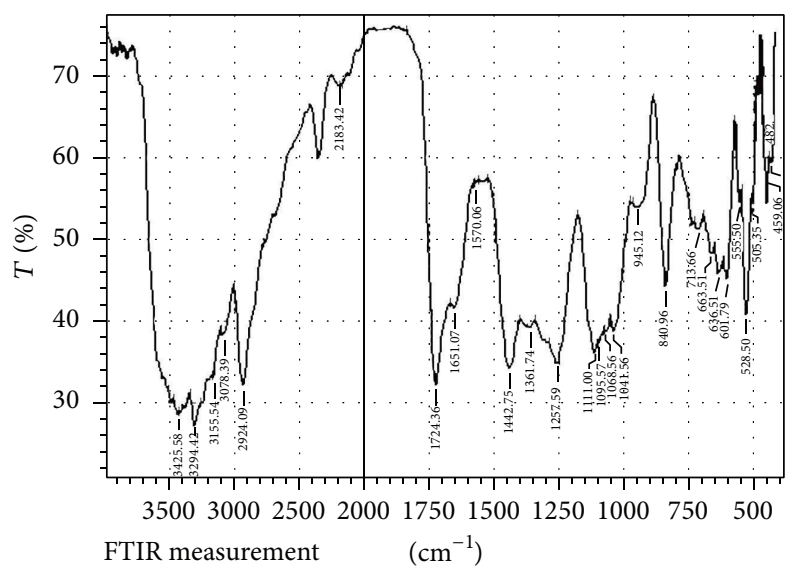

(b)

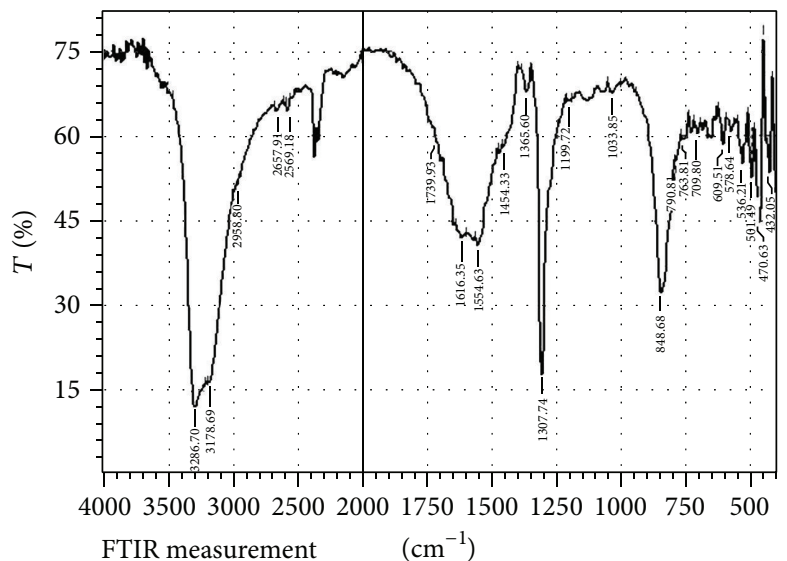

(d)

Figure 4: FTIR graph of PVAc/[Co( $\left(\mathrm{NH}_{3}\right)_{5} \mathrm{Cl}_{3} \mathrm{Cl}_{2}$ composites film with different concentrations: (a) pure PVAc, (b) 3 wt.\% (c) 6 wt.\%, and (d) 9 wt.\%.

These results were confirmed by XRD results. From Figure 6, a small absorption band at about $500 \mathrm{~nm}$ was observed. Formation of new peaks for the samples and also broadening of those peaks with increasing $\left[\mathrm{Co}\left(\mathrm{NH}_{3}\right)_{5} \mathrm{Cl}\right] \mathrm{Cl}_{2}$ indicate a considerable interaction between additive and host polymer [30]. Also Figure 6 shows that the absorbance increases by adding different weight percentages of $\left[\mathrm{Co}\left(\mathrm{NH}_{3}\right)_{5} \mathrm{Cl}_{\mathrm{Cl}} \mathrm{Cl}_{2}\right.$; this is related to absorbance of $\left[\mathrm{Co}\left(\mathrm{NH}_{3}\right)_{5} \mathrm{Cl}\right] \mathrm{Cl}_{2}$ or, in other words, the absorbance increases with percentages of absorbed particles [31]. The absorption at any wavelength depends on the number of particles along the bath of the incident light (i.e., it depends on concentration of $\left[\mathrm{Co}\left(\mathrm{NH}_{3}\right)_{5} \mathrm{Cl}_{2} \mathrm{Cl}_{2}\right)$ and on the length of the optical path passing through [32]. These results have a good agreement with Abdelaziz [18].

Absorption coefficient $(\alpha)$ is defined as the ability of a material to absorb the light of a given wavelength. The absorption coefficient was calculated from the optical absorbance (A) by the following relation [33]:

$$
\alpha=2.303 \times \frac{A}{t} .
$$

Figure 7 shows the variation of the absorption coefficient with photon energy for $\mathrm{PVAc} / 0, \mathrm{PVAc} / 3, \mathrm{PVAc} / 6$, and PVAc $/ 9$ wt. $\%$ of $\left[\mathrm{Co}\left(\mathrm{NH}_{3}\right)_{5} \mathrm{Cl}\right] \mathrm{Cl}_{2}$ composites films. It is clear that the absorption coefficient is increasing with concentration of $\left[\mathrm{Co}\left(\mathrm{NH}_{3}\right)_{5} \mathrm{Cl}\right] \mathrm{Cl}_{2}$; this may be attributed to increase in the absorbance [34]. Figure 7 also shows the dependence of absorption coefficient on incident photon energy, indicated from the low value of absorption coefficient with low value of photon energy and vice versa which means that the possibility of electron transition is increasing with photon energy.

From the absorption coefficient previous results, the electron transition of $\mathrm{PVAc} /\left[\mathrm{Co}\left(\mathrm{NH}_{3}\right)_{5} \mathrm{Cl}\right] \mathrm{Cl}_{2}$ is indirect. A good linear fit is obtained for $(\alpha h v)^{1 / 2}$ and $(\alpha h v)^{1 / 3}$ versus $h v$ as shown in Figures 8 and 9, respectively. The respective values of $E_{g}$ are obtained by extrapolating to $(\alpha h v)^{1 / 2}=0$ and $(\alpha h v)^{1 / 3}=0$ for the allowed indirect transition and forbidden indirect transition, respectively. Content is responsible for the formation of some defects in the films. These defects produce the localized states in the optical band gap and overlap. These overlaps give an evidence for decreasing energy band gap when the $\left[\mathrm{Co}\left(\mathrm{NH}_{3}\right)_{5} \mathrm{Cl}\right] \mathrm{Cl}_{2}$ content is increased in 


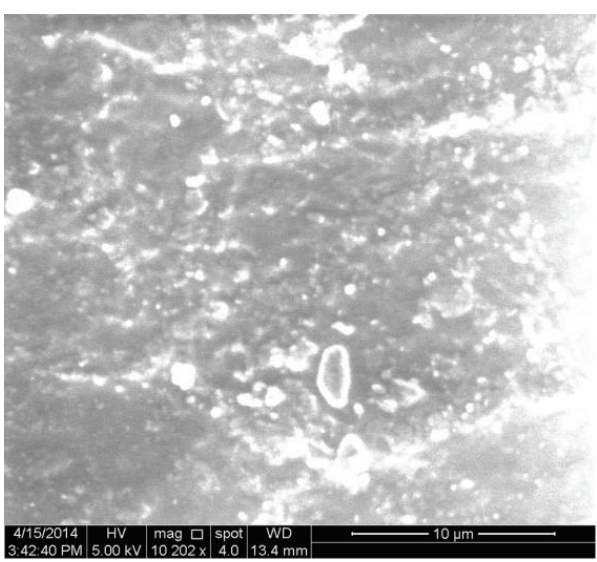

(a)

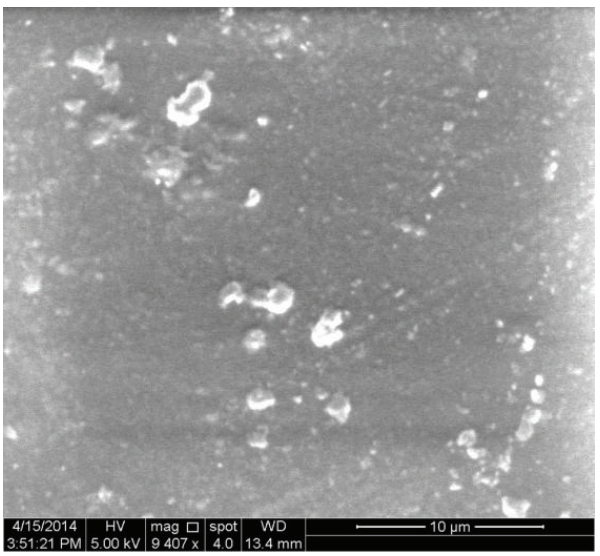

(c)

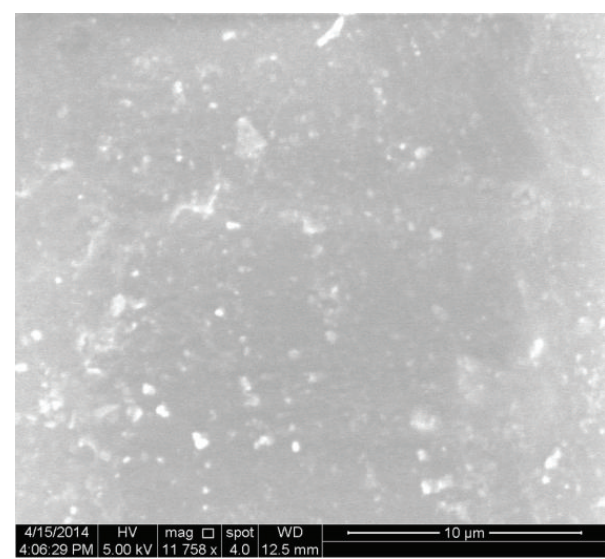

(b)

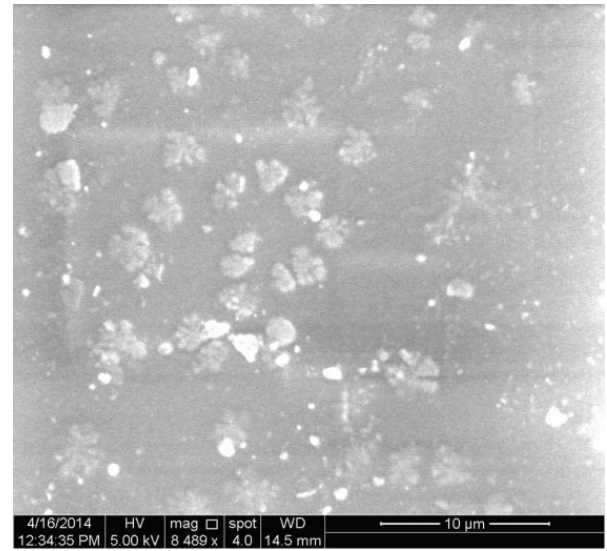

(d)

FIGURE 5: SEM photographs for PVAc/[Co( $\left.\left.\mathrm{NH}_{3}\right)_{5} \mathrm{Cl}\right] \mathrm{Cl}_{2}$ composite films with different concentrations of $\left[\mathrm{Co}\left(\mathrm{NH}_{3}\right)_{5} \mathrm{Cl}\right] \mathrm{Cl}{ }_{2}$ : (a) 0 wt.\%, (b) 3 wt.\%, (c) 6 wt.\%, and (d) 9 wt.\%.

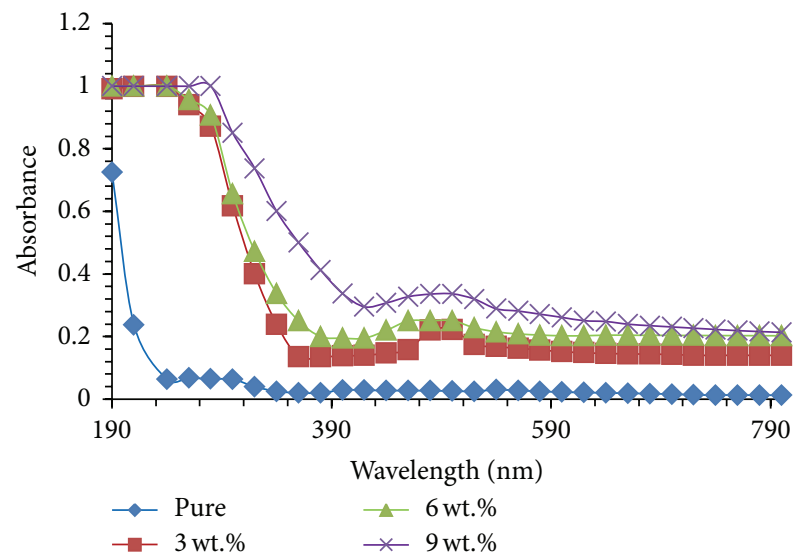

Figure 6: Optical absorption as a function of wavelength for PVAc with $0,3,6$, and 9 wt.\% concentration of $\left[\mathrm{Co}\left(\mathrm{NH}_{3}\right)_{5} \mathrm{Cl}\right] \mathrm{Cl}_{2}$ at room temperature.

the polymeric matrix as shown in Figures 8 and 9. In other words the decrease in the optical gap reflects the increase in the degree of disorder in the PVAc films. Abdelaziz and Ghannam [35] observed similar results, respectively. Or it can

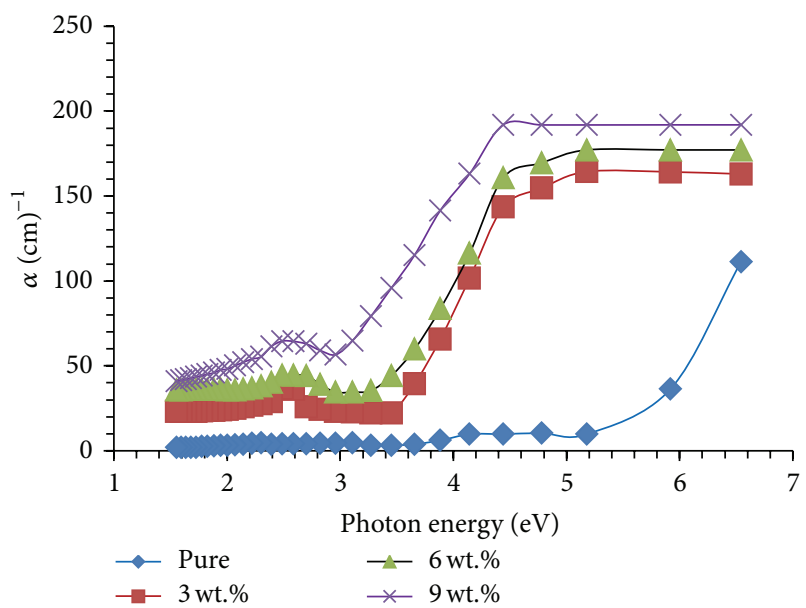

FIGURE 7: The absorption coefficient for PVAc with $0,3,6$, and 9 wt. $\%$ concentration of $\left[\mathrm{Co}\left(\mathrm{NH}_{3}\right)_{5} \mathrm{Cl}\right] \mathrm{Cl}_{2}$ composites versus photon energy.

be attributed to the additive complexation with the polymer matrix [36]. These results agree with FTIR, SEM, and XRD observations. 


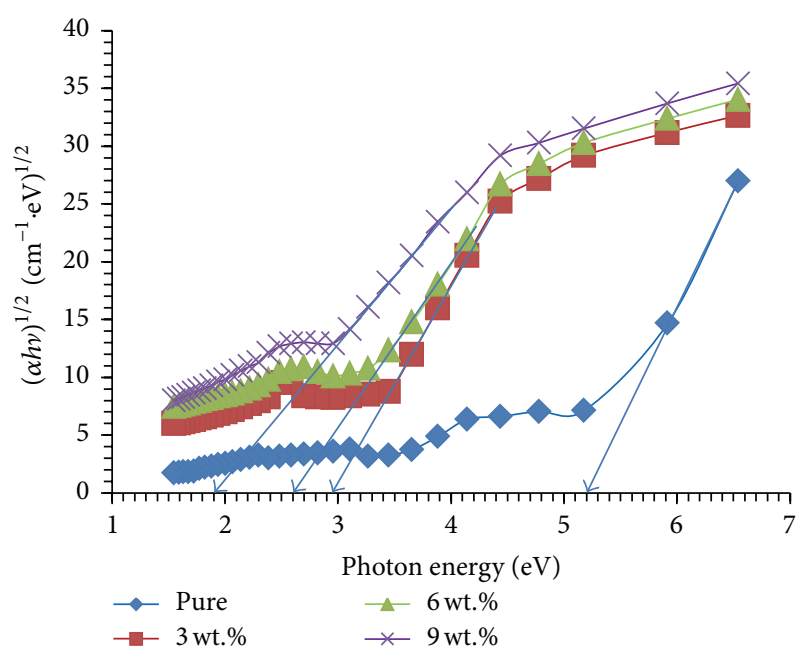

FIGURE 8: $(\alpha h v)^{1 / 2}$ versus photon energy of PVAc/0, PVAc/3, PVAc/6, and PVAc/9 wt.\% of $\left[\mathrm{Co}\left(\mathrm{NH}_{3}\right)_{5} \mathrm{Cl}\right] \mathrm{Cl}_{2}$ composites.

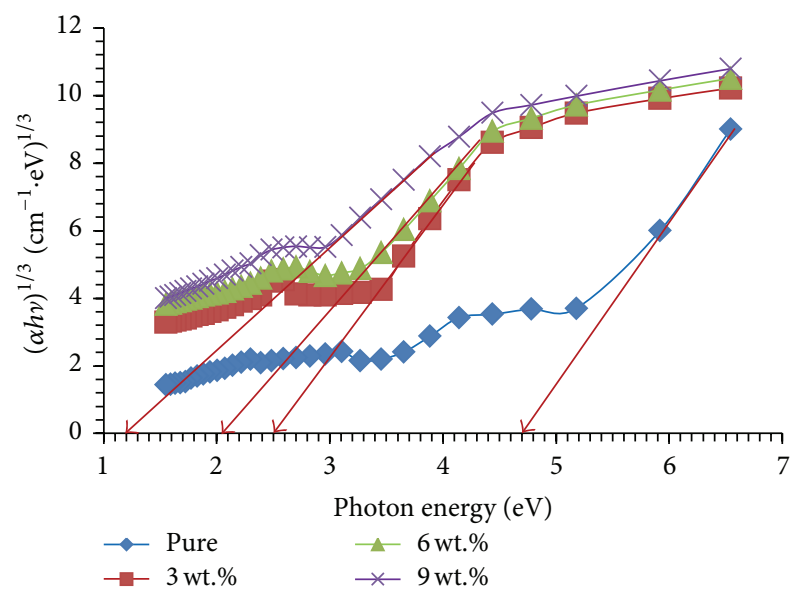

Figure 9: $(\alpha h v)^{1 / 3}$ versus photon energy of PVAc/0, PVAc/3, PVAc/6, and PVAc/9 wt.\% of $\left[\mathrm{Co}\left(\mathrm{NH}_{3}\right)_{5} \mathrm{Cl}\right] \mathrm{Cl}_{2}$ composites.

Figure 10 shows the values of energy gap for indirect transition (allowed and forbidden) for (PVAc/0, PVAc/3, PVAc/6, and PVAc/9 wt.\% $\left.\left[\mathrm{Co}\left(\mathrm{NH}_{3}\right)_{5} \mathrm{Cl}\right] \mathrm{Cl}_{2}\right)$ composites.

The extinction coefficient $(K)$ was calculated using the following equation [37]:

$$
K=\frac{\alpha \lambda}{4 \pi}
$$

The dependence of the extinction coefficient $(K)$ on the wavelength in the range $190-800 \mathrm{~nm}$ of PVAc/ $\left[\mathrm{Co}\left(\mathrm{NH}_{3}\right)_{5} \mathrm{Cl}\right] \mathrm{Cl}_{2}$ composites samples is shown in Figure 11. It is clear that the extinction coefficient for pure PVAc sample shows a decrease in values of the all wavelengths (190-800) nm, while it increases for PVAc/0, PVAc/3, PVAc/6, and PVAc/9 wt.\% of $\left[\mathrm{Co}\left(\mathrm{NH}_{3}\right)_{5} \mathrm{Cl}_{\mathrm{Cl}_{2}}\right.$ in the wavelength from $400 \mathrm{~nm}$ to $800 \mathrm{~nm}$. Extinction coefficient was increased for PVAc films with increasing the concentration of $\left[\mathrm{Co}\left(\mathrm{NH}_{3}\right)_{5} \mathrm{Cl}\right] \mathrm{Cl}_{2}$; this is due to the increase in absorption coefficient [7].

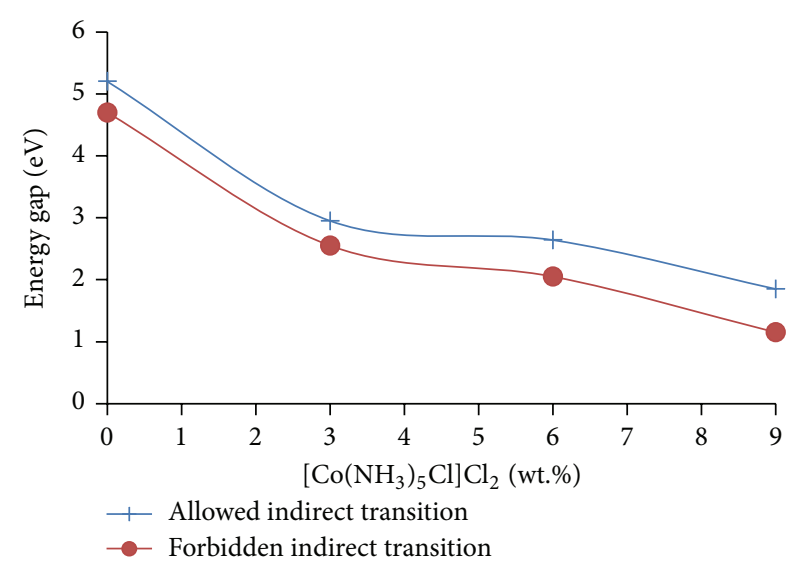

Figure 10: Energy gap of PVAc/0, PVAc/3, PVAc/6, and PVAc/ 9 wt. $\%$ of $\left[\mathrm{Co}\left(\mathrm{NH}_{3}\right)_{5} \mathrm{Cl}\right] \mathrm{Cl}_{2}$ composites versus the concentration of $\left[\mathrm{Co}\left(\mathrm{NH}_{3}\right)_{5} \mathrm{Cl}\right] \mathrm{Cl}_{2}$.

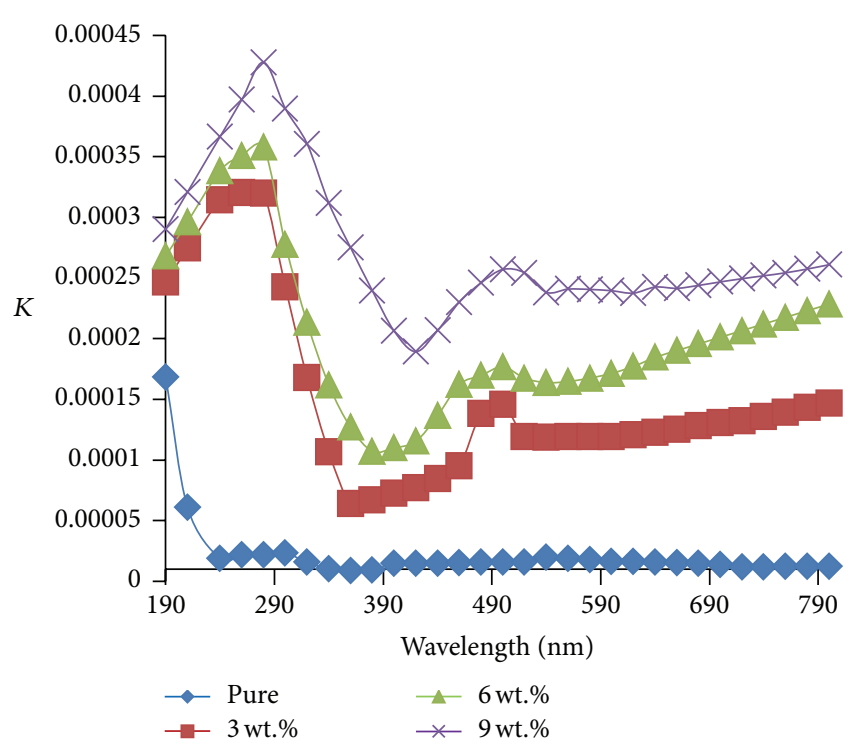

Figure 11: Extinction coefficient of PVAc/0, PVAc/3, PVAc/6, and $\mathrm{PVAc} / 9$ wt.\% of $\left[\mathrm{Co}\left(\mathrm{NH}_{3}\right)_{5} \mathrm{Cl}\right] \mathrm{Cl}_{2}$ composites versus wavelength.

The refractive index $(n)$ is a fundamental optical property of polymers that is directly related to other optical, electrical, and magnetic properties and is also of interest to those studying the physical, chemical, and molecular properties of polymers by optical techniques [38]. The refractive index is calculated by [39]

$$
n=\sqrt[2]{\frac{4 R-K^{2}}{(R-1)^{2}}}-\frac{(R+1)}{(R-1)},
$$

where $R$ is reflectance which is obtained from absorption $A$ and transmission $T$ spectra in accordance with conservation of energy law $R+A+T=1$ [40]. Figure 12 represents the refractive index for $\mathrm{PVAc} / 0, \mathrm{PVAc} / 3, \mathrm{PVAc} / 6$, and PVAc/9 wt.\% of $\left[\mathrm{Co}\left(\mathrm{NH}_{3}\right)_{5} \mathrm{Cl}\right] \mathrm{Cl}_{2}$ composites films in the investigated range of wavelengths. Inspection of Figure 12 indicates for all compositions that the refractive index 


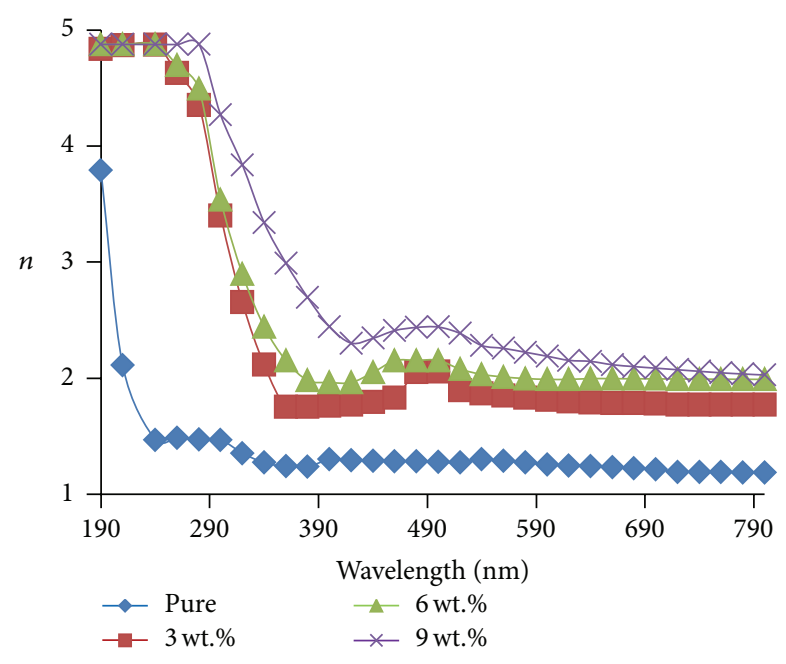

FIgURE 12: Refractive index of PVAc/0, PVAc/3, PVAc/6, and PVAc $/ 9$ wt. $\%$ of $\left[\mathrm{Co}\left(\mathrm{NH}_{3}\right)_{5} \mathrm{Cl}\right] \mathrm{Cl}_{2}$ composites versus wavelength.

decreases with increasing wavelength. The figure shows that the refractive index increases as a result of increasing in the percentage of $\left[\mathrm{Co}\left(\mathrm{NH}_{3}\right)_{5} \mathrm{Cl}\right] \mathrm{Cl}_{2}$ which is due to the increasing of the density of composites film as a result of $\left[\mathrm{Co}\left(\mathrm{NH}_{3}\right)_{5} \mathrm{Cl}\right] \mathrm{Cl}_{2}$ content. In the literature, the relationship between refractive index and mass density is described as linear [41]. Increasing in refractive index with concentration of $\left[\mathrm{Co}\left(\mathrm{NH}_{3}\right)_{5} \mathrm{Cl}\right] \mathrm{Cl}_{2}$ is a result of increasing the number of atomic refractions due to the increase of the linear polarizability which agree with Lorentz-Lorentz formula [34].

Dielectric constant is defined as the response of the material toward the incident electromagnetic field. The dielectric constant of $(\varepsilon)$ is given by the following equation [42]:

$$
\varepsilon=\varepsilon_{1}-i \varepsilon_{2}
$$

where $\left(\varepsilon_{1}\right)$ and $\left(\varepsilon_{2}\right)$ are the real and the imaginary parts of dielectric constant, respectively, which can be obtained by the following equations [43]:

$$
\begin{gathered}
\varepsilon_{1}=n^{2}-k^{2}, \\
\varepsilon_{2}=2 n k .
\end{gathered}
$$

The dependence of the real part on the wavelength is shown in Figure 13 for PVAc/0, PVAc/3, PVAc/6, and PVAc/9 wt.\% of $\left[\mathrm{Co}\left(\mathrm{NH}_{3}\right)_{5} \mathrm{Cl}\right] \mathrm{Cl}_{2}$. It can be noticed, from this figure, that the real part depends on refractive index because the effect of extinction coefficient is very small so, it could be canceling [35]. The real part of dielectric constant is increases with $\left[\mathrm{Co}\left(\mathrm{NH}_{3}\right)_{5} \mathrm{Cl}\right] \mathrm{Cl}_{2}$ concentration and the curves vertex shifted to higher wavelengths with increasing $\left[\mathrm{Co}\left(\mathrm{NH}_{3}\right)_{5} \mathrm{Cl}\right] \mathrm{Cl}_{2}$ percentage which may attributed to the dependency of the real part of dielectric constant on refractive index [43]. The imaginary part of dielectric constant as a function of wavelength is shown in Figure 14. It is clear that the imaginary part depends on extinction coefficient especially in the range of wavelength around (390-800) where

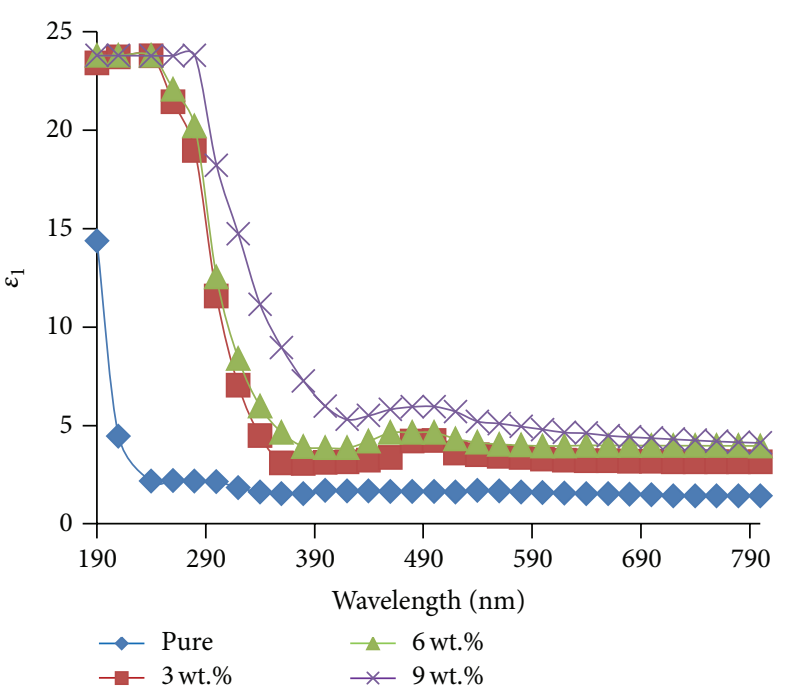

FIgURE 13: Real part of dielectric constant of PVAc/0, PVAc/3, PVAc/6, and PVAc/9 wt.\% of $\left[\mathrm{Co}\left(\mathrm{NH}_{3}\right)_{5} \mathrm{Cl}_{\mathrm{Cl}} \mathrm{Cl}_{2}\right.$ composites versus wavelength.

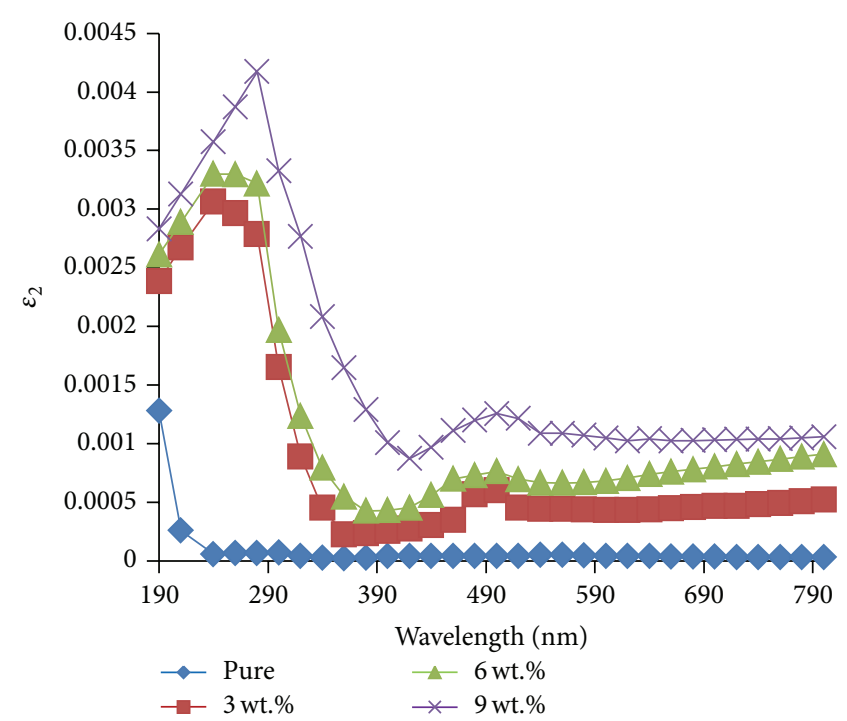

FIGURE 14: Imaginary part of dielectric constant of PVAc/0, PVAc/3, PVAc/6, and PVAc/9 wt.\% of $\left[\mathrm{Co}\left(\mathrm{NH}_{3}\right)_{5} \mathrm{Cl}_{\mathrm{Cl}}\right.$ composites versus wavelength.

the refractive index stays almost constant while extinction coefficient increases with wavelength [34, 43].

The absorption coefficient and the refractive index were used to obtain the optical conductivity $(\sigma)$, by the following relation [44]:

$$
\sigma=\frac{\alpha n c}{4 \pi},
$$

where $c$ is the velocity of light in the space. Figure 15 shows the variation of optical conductivity of PVAc/0, $\mathrm{PVAc} / 3, \mathrm{PVAc} / 6$, and PVAc/9 wt.\% of $\left[\mathrm{Co}\left(\mathrm{NH}_{3}\right)_{5} \mathrm{Cl}\right] \mathrm{Cl}_{2}$ composites films, as a function of photon energy. The conductivity of pure PVA is almost constant up to around $5.2 \mathrm{eV}$ of photon energy, 


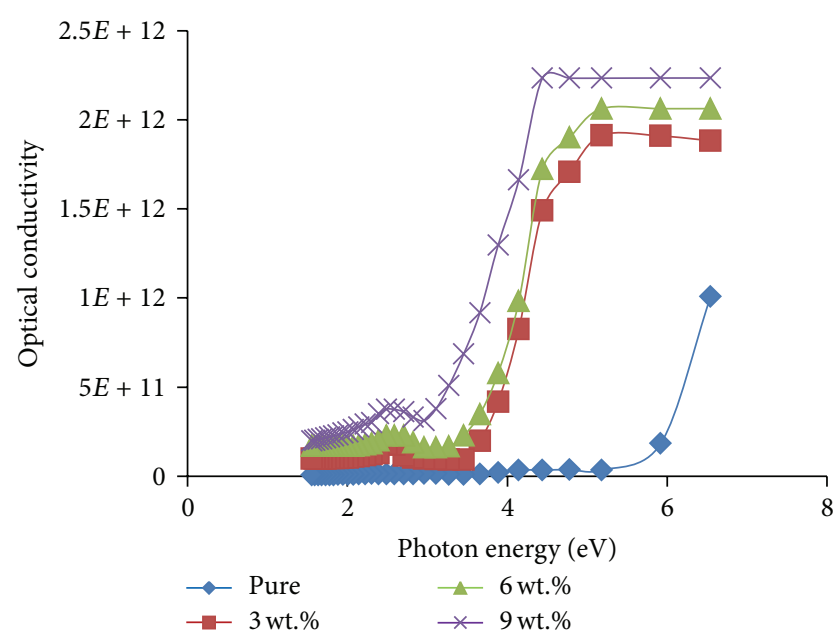

Figure 15: The optical conductivity PVAc/0, PVAc/3, PVAc/6, and PVAc $/ 9$ wt.\% of $\left[\mathrm{Co}\left(\mathrm{NH}_{3}\right)_{5} \mathrm{Cl}\right] \mathrm{Cl}_{2}$ composites films as a function of photon energy.

after that it increases with increase in photon energy. The $\left[\mathrm{Co}\left(\mathrm{NH}_{3}\right)_{5} \mathrm{Cl}\right] \mathrm{Cl}_{2}$ concentration caused the increase in optical conductivity, which is due to high absorbance of the polymer composites films. The increase in optical conductance, and decrease in band gap energy of PVAc/ $\left[\mathrm{Co}\left(\mathrm{NH}_{3}\right)_{5} \mathrm{Cl}\right] \mathrm{Cl}_{2}$ with increase of $\left[\mathrm{Co}\left(\mathrm{NH}_{3}\right)_{5} \mathrm{Cl}\right] \mathrm{Cl}_{2}$ concentration, can be attributed to the increase in number of mobile charge carriers and also to the increase in amorphous nature of host polymer [45]. These results agree with Al-Taa'y et al. [7].

\section{Conclusions}

Polymer films based on PVAc with different concentrations of $\left[\mathrm{Co}\left(\mathrm{NH}_{3}\right)_{5} \mathrm{Cl}\right] \mathrm{Cl}_{2}$ were prepared using solvent casting technique. XRD reviled that the synthesized $\left[\mathrm{Co}\left(\mathrm{NH}_{3}\right)_{5} \mathrm{Cl}\right] \mathrm{Cl}_{2}$ was indexed to orthorhombic structure. The formation of an intermolecular interaction and complexation between PVAc and $\left[\mathrm{Co}\left(\mathrm{NH}_{3}\right)_{5} \mathrm{Cl}\right] \mathrm{Cl}_{2}$ has been confirmed using XRD, FTIR, SEM, and UV. The UV results indicated that $\left[\mathrm{Co}\left(\mathrm{NH}_{3}\right)_{5} \mathrm{Cl}\right] \mathrm{Cl}_{2}$ can effectively enhance the optical properties of PVAc. The absorption coefficient increased with increasing of the weight percentage of the additive. The increase in optical conductance and decrease in energy band gap of polymer host matrix with increase of $\left[\mathrm{Co}\left(\mathrm{NH}_{3}\right)_{5} \mathrm{Cl}\right] \mathrm{Cl}_{2}$ concentration were attributed to the increase in number of mobile charge carriers and also to the increase in amorphous nature of the polymer host matrix. The optical constants such as extinction coefficients, refractive index, real and imaginary dielectric constants, and optical conductance are found to depend on the concentration of $\left[\mathrm{Co}\left(\mathrm{NH}_{3}\right)_{5} \mathrm{Cl}\right] \mathrm{Cl}_{2}$ in the polymer film. PVAc/9 wt.\% $\left[\mathrm{Co}\left(\mathrm{NH}_{3}\right)_{5} \mathrm{Cl}\right] \mathrm{Cl}_{2}$ composites films show the best optical properties. This type of composites could be a suitable candidate for photovoltaic cells, although further studies and enhancement are desired. Also, this work confirms that the refractive index and energy gap are strongly correlated.
In summary, the measurements of optical properties indicate that the $\left[\mathrm{Co}\left(\mathrm{NH}_{3}\right)_{5} \mathrm{Cl}\right] \mathrm{Cl}_{2}$ is useful additive to simultaneously increase both absorbance and optical conductivity of PVAc. As a result, the PVAc/ $\left[\mathrm{Co}\left(\mathrm{NH}_{3}\right)_{5} \mathrm{Cl}\right] \mathrm{Cl}_{2}$ composite film shows dramatic changes in optical properties which help it in optical devices fabrication.

\section{Conflict of Interests}

The authors declare that there is no conflict of interests regarding the publication of this paper.

\section{Acknowledgments}

The authors gratefully acknowledge Dr. Nadher Najem for helpful discussions during the development of this work; also they want to express their deep procreation for Dr. Mohammed Hadi for his helpful assistance in XRD measurement.

\section{References}

[1] G. H. Michler and F. J. Baltá-Colleja, Mechanical Properties of Polymers Based on Nanostructure and Morphology, Taylor \& Francis, Boca Raton, Fla, USA, 2005.

[2] N. M. Albuquerque, Photolithography: A Manual, Tamarind Institute, 2002.

[3] D. R. Askeland, P. P. Fulay, and W. J. Wright, The Science and Engineering of Materials, Cengage Learning, 6th edition, 2010.

[4] E. M. Abdelrazek, I. S. Elashmawi, A. El-khodary, and A. Yassin, "Structural, optical, thermal and electrical studies on PVA/PVP blends filled with lithium bromide," Current Applied Physics, vol. 10, no. 2, pp. 607-613, 2010.

[5] L. N. Ismail, H. Zulkefle, S. H. Herman, and M. Rusop Mahmood, "Influence of doping concentration on dielectric, optical, and morphological properties of PMMA thin films," Advances in Materials Science and Engineering, vol. 2012, Article ID 605673, 4 pages, 2012.

[6] K. H. Tagreed, "Refractive index dispersion and analysis of the optical parameters of (PMMA/PVA) thin film," Journal of AlNahrain University, vol. 16, pp. 164-170, 2013.

[7] W. Al-Taa'y, M. Abdul Nabi, R. M. Yusop et al., "Effect of nano $\mathrm{ZnO}$ on the optical properties of poly(vinyl chloride) films," International Journal of Polymer Science, vol. 2014, Article ID 697809, 6 pages, 2014.

[8] C. S. Choi, B. J. Park, and H. J. Choi, "Electrical and rheological characteristics of poly(vinyl acetate)/multi-walled carbon nanotube nanocomposites," Diamond and Related Materials, vol. 16, no. 4-7, pp. 1170-1173, 2007.

[9] L. Dong, C. Xiong, H. Quan, and G. Zhao, "Polyvinylbutyral/lead zirconate titanates composites with high dielectric constant and low dielectric loss," Scripta Materialia, vol. 55, no. 9, pp. 835-837, 2006.

[10] G. Wulfsberg, Inorganic Chemistry, University Science Books, 2000.

[11] I. I. Mikhalenko, Y. A. Zubarev, L. V. Krasnyi-Admoni, and V. D. Yagodovskii, "complexation of palladium in sorption by polyacrylonitrile fiber-poly-2-methyl-5-," Journal of Applied Chemistry USSR, vol. 63, pp. 1337-1341, 1990. 
[12] S. Young Tyree Jr., "Chloropentaamminecobalt (III) chloride," in Inorganic Syntheses, vol. 9, chapter 43, McGraw-Hill, 1967.

[13] T. Brown, E. LeMay, and B. Bursten, Chemistry: The Central Science, Pearson Education, 9th edition, 2002.

[14] S. Kirk, L. Solovyev, A. Blokhin, and P. Mulagaleev, ICDD Grantin-Aid, Academy of Science, Krasnoyarsk, Russia, 2000.

[15] E. Sheha, H. Khoder, T. S. Shanap, M. G. El-Shaarawy, and M. K. El Mansy, "Structure, dielectric and optical properties of p-type (PVA/CuI) nanocomposite polymer electrolyte for photovoltaic cells," Optik, vol. 123, no. 13, pp. 1161-1166, 2012.

[16] Y. A. Badr, K. M. Abd El-Kader, and R. M. Khafagy, "Raman spectroscopy study of CdS, PVA composite films," Journal of Applied Polymer Science, vol. 92, no. 3, pp. 1984-1992, 2004.

[17] M. A. Ahmed, R. M. Khafagy, S. T. Bishay, and N. M. Saleh, "Effective dye removal and water purification using the electric and magnetic $\mathrm{Zn}_{0.5} \mathrm{Co}_{0.5} \mathrm{Al}_{0.5} \mathrm{Fe}_{1.46} \mathrm{La}_{0.04} \mathrm{O}_{4}$ /polymer core-shell nanocomposites," Journal of Alloys and Compounds, vol. 578, pp. 121-131, 2013.

[18] M. Abdelaziz, "Optical and dielectric properties of poly(vinylacetate)/lead oxide composites," Journal of Materials Science: Materials in Electronics, vol. 23, no. 7, pp. 1378-1386, 2012.

[19] J. Ahmad and M. B. Hågg, "Polyvinyl acetate/titanium dioxide nanocomposite membranes for gas separation," Journal of Membrane Science, vol. 445, pp. 200-210, 2013.

[20] A. S. Roy, S. Gupta, S. Sindhu, A. Parveen, and P. C. Ramamurthy, "Dielectric properties of novel PVA/ZnO hybrid nanocomposite films," Composites Part B: Engineering, vol. 47, pp. 314-319, 2013.

[21] W. Haas, M. Zrinyi, H.-G. Kilian, and B. Heise, "Structural analysis of anisometric colloidal iron(III)-hydroxide particles and particle-aggregates incorporated in poly(vinyl-acetate) networks," Colloid \& Polymer Science, vol. 271, no. 11, pp. 1024-1034, 1993.

[22] M. H. Najar and K. Majid, "Synthesis, characterization, electrical and thermal properties of nanocomposite of polythiophene with nanophotoadduct: a potent composite for electronic use," Journal of Materials Science: Materials in Electronics, vol. 24, no. 11, pp. 4332-4339, 2013.

[23] C. J. Pouchert, The Aldrich Library of Infrared Spectra, vol. 2, 3rd edition, 1981.

[24] Z. Qiao, Y. Xie, M. Chen, J. Xu, Y. Zhu, and Y. Qian, "Synthesis of lead sulfide/(polyvinyl acetate) nanocomposites with controllable morphology," Chemical Physics Letters, vol. 321, no. 5-6, pp. 504-507, 2000.

[25] G. K. Prajapati, R. Roshan, and P. N. Gupta, "Effect of plasticizer on ionic transport and dielectric properties of $\mathrm{PVAH}_{3} \mathrm{PO}_{4}$ proton conducting polymeric electrolytes," Journal of Physics and Chemistry of Solids, vol. 71, no. 12, pp. 1717-1723, 2010.

[26] G. R. Dhokane, "Preparation and characterization of Fe+++ doped dipyridine polyvinyl acetate supported composite films," Online International Interdisciplinary Research Journal, vol. 4, pp. 183-188, 2014.

[27] N. Shah, D. Singh, S. Shah, A. Qureshi, N. L. Singh, and K. P. Singh, "Study of microhardness and electrical properties of proton irradiated polyethersulfone (PES)," Bulletin of Materials Science, vol. 30, no. 5, pp. 477-480, 2007.

[28] H. M. Zidan, A. Tawansi, and M. Abu-Elnader, "Miscibility, optical and dielectric properties of UV-irradiated poly(vinylacetate)/poly(methylmethacrylate) blends," Physica B, vol. 339, no. 2-3, pp. 78-86, 2003.
[29] E. M. Abdelrazek and I. S. Elashmawi, "Characterization and physical properties of $\mathrm{CoCl}_{2}$ filled polyethyl-methacrylate films," Polymer Composites, vol. 29, no. 9, pp. 1036-1043, 2008.

[30] A. Wasan, T. Mohammed, and K. Tagreed, "The MR affect on optical properties for poly (Vinyl alcohol) films," Journal of Baghdad for Science, vol. 8, pp. 543-550, 2011.

[31] H. H. A. B. Al-Shammari, Preparation of polymer composites ((PVA-ZnO), (PVA-CuSO4.5H2O)) and studying some of its electrical and optical properties [M.S. thesis], University of Babylon, 2011.

[32] P. U. Asogwa, "Band gap shift and optical characterization of PVA-capped $\mathrm{PbO}$ thin films: effect of thermal annealing," Chalcogenide Letters, vol. 8, no. 3, pp. 163-170, 2011.

[33] I. S. Elashmawi and N. A. Hakeem, "Effect of PMMA addition on characterization and morphology of PVDF," Polymer Engineering \& Science, vol. 48, no. 5, pp. 895-901, 2008.

[34] A. H. Ahmad, A. M. Awatif, and N. Zeid Abdul-Majied, "Doping effect on optical constants of poly methyl methacrylate (PMMA)," The Journal of Engineering Technology, vol. 25, pp. 558-568, 2007.

[35] M. Abdelaziz and M. M. Ghannam, "Influence of titanium chloride addition on the optical and dielectric properties of PVA films," Physica B: Condensed Matter, vol. 405, no. 3, pp. 958-964, 2010.

[36] M. K. El-Mansy, E. M. Sheha, K. R. Patel, and G. D. Sharma, "Characterization of PVA/CuI polymer composites as electron donor for photovoltaic application," Optik, vol. 124, no. 13, pp. 1624-1631, 2013.

[37] M. Balkanski, Optical Properties of Solids, North-Holland, New York, NY, USA, 1992.

[38] J. Gao, J. Xu, B. Chen, and Q. Zhang, "A quantitative structureproperty relationship study for refractive indices of conjugated polymers," Journal of Molecular Modeling, vol. 13, no. 5, pp. 573578, 2007.

[39] F. I. Ezema, P. U. Asogwa, A. B. C. Ekwealor, P. E. Ugwuoke, and R. U. Osuji, "Growth and optical properties of $\mathrm{Ag}_{2} \mathrm{~S}$ thin films deposited by chemical bath deposition technique," Journal of the University of Chemical Technology and Metallurgy, vol. 42, pp. 217-222, 2007.

[40] J. I. Gittleman, E. K. Sichel, and Y. Arie, "Composite semiconductors: selective absorbers of solar energy," Solar Energy Materials, vol. 1, no. 1-2, pp. 93-104, 1979.

[41] D. Mergel and M. Jerman, "Density and refractive index of thin evaporated films," Chinese Optics Letters, vol. 8, pp. 67-72, 2010.

[42] B. O. Seraphin, Optical Properties of Solid New Developments, American Elsevier Publishing, New York, NY, USA, 2nd edition, 1976.

[43] G. A. Khadum, "Study the optical constant of cadmium oxide films doped with silver oxide (CdO: $\left.\mathrm{Ag}_{2} \mathrm{O}\right)$ in infrared region," Diala Journal, vol. 32, pp. 178-162, 2009.

[44] R. Das and S. Pandey, "Comparison of optical properties of bulk and nano crystalline thin films of CdS using different precursors," International Journal of Material Science, vol. 1, pp. 35-40, 2011.

[45] S. Selvasekarapandian, M. Hema, J. Kawamura, O. Kamishima, and R. Baskaran, "Characterization of PVA- $\mathrm{NH}_{4} \mathrm{NO}_{3}$ polymer electrolyte and its application in rechargeable proton battery," Journal of the Physical Society of Japan, vol. 79, pp. 163-168, 2010. 

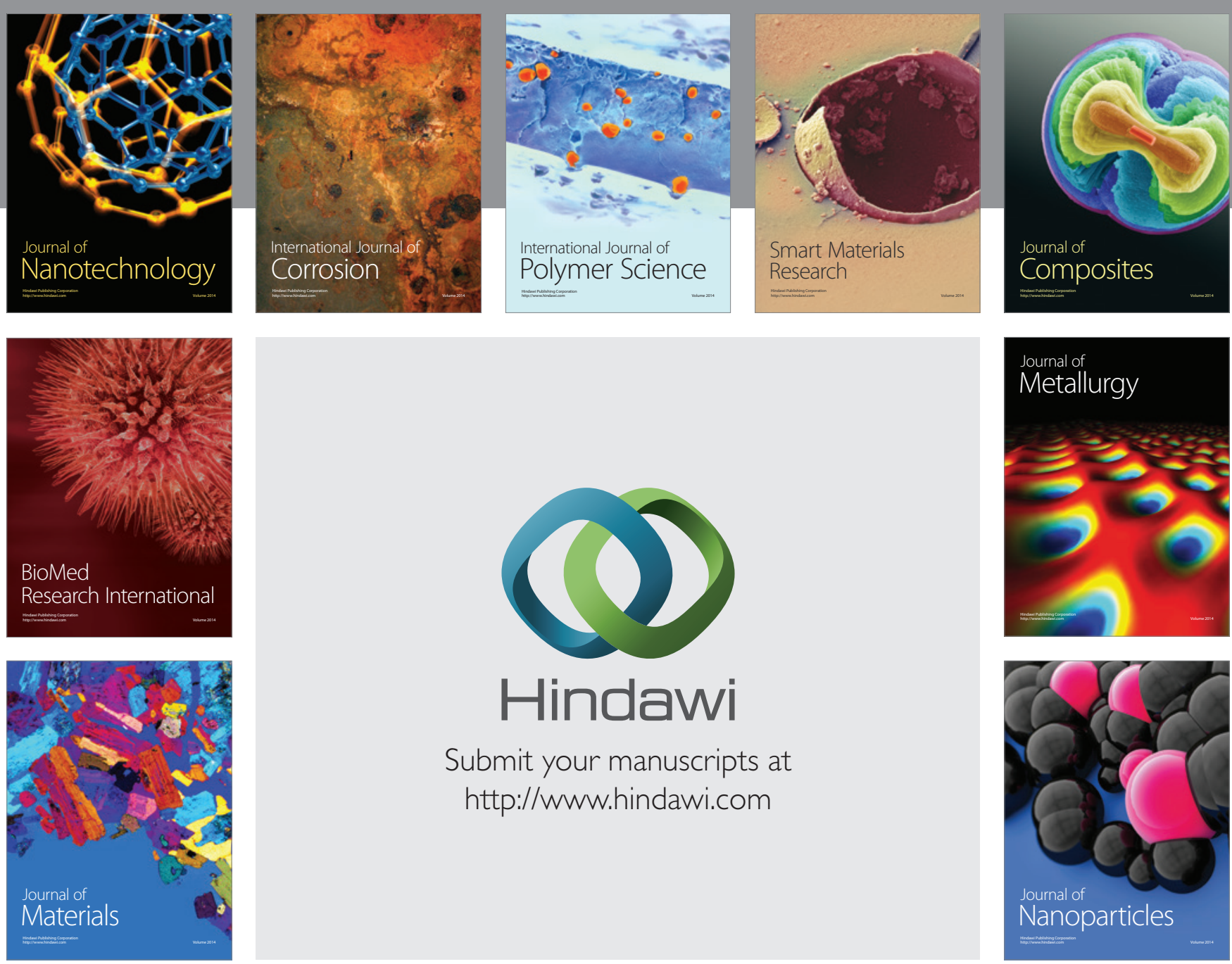

Submit your manuscripts at http://www.hindawi.com
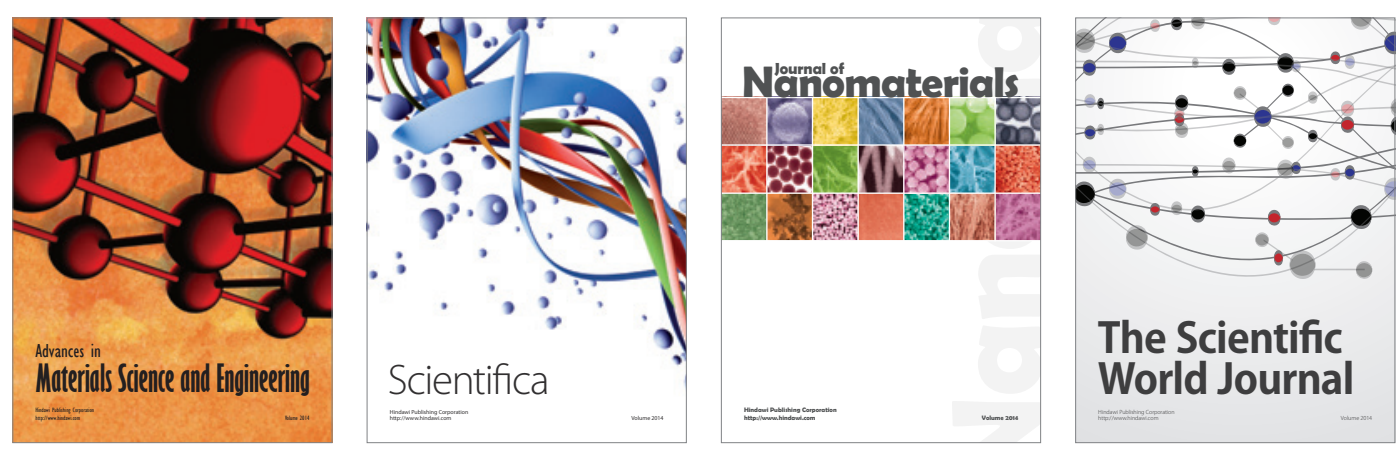

\section{The Scientific World Journal}
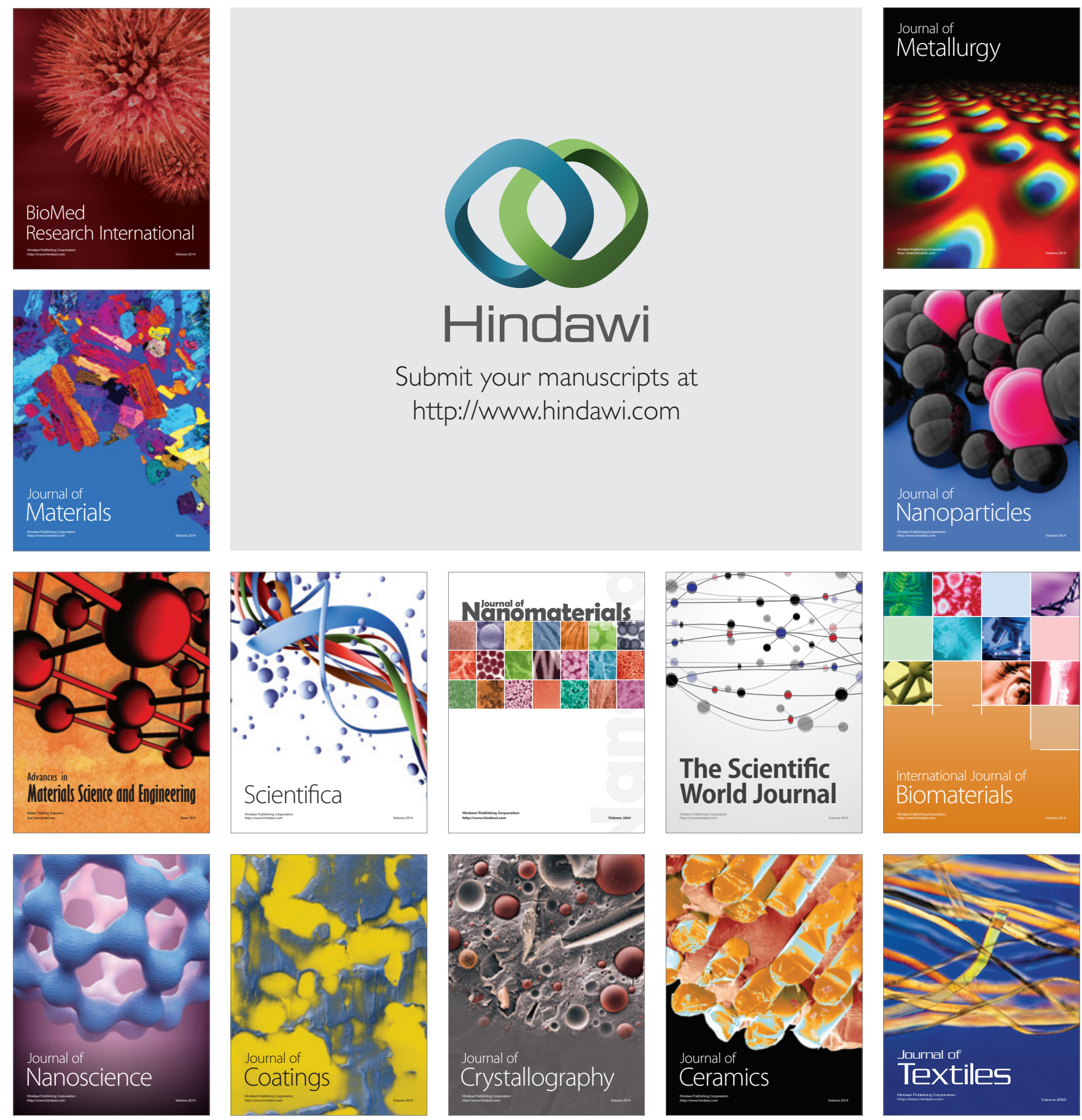